\title{
25 Research Suare \\ Effect of the Slope Angle and Its Classification on Landslide
}

Seda Çellek ( $\nabla$ sedacellek@ahievran.edu.tr)

Kırşehir Ahi Evran University

Research article

Keywords: Landslide, susceptibility, parameter, slope angle, classification, Turkey

Posted Date: August 31st, 2020

DOl: https://doi.org/10.21203/rs.3.rs-61660/v1

License: (c) (i) This work is licensed under a Creative Commons Attribution 4.0 International License.

Read Full License 


\section{Abstract}

The preparation of landslide susceptibility maps is a complex process with regards to the selection of the study field, parameters, and methods. The phase after the determination of the landslide distribution in landslide susceptibility studies is the selection of the methods and parameters to be used. However, first, as in this study, a comprehensive literature search is required. A review of approximately 1500 randomly selected publications revealed that it was necessary to select a parameter based on the area, and the research showed that, in each study, the most preferred parameter was the slope angle. Moreover, there is nearly a consensus of opinion among researchers regarding the use of the slope angle. The current research included the definitions of the slope angle put forth by different researchers, the advantages and disadvantages of its use, the different classifications that have been used, the intervals of the landslides, its use together with other parameters, and its effect on landslides. Generally, it was observed that automatic slope angle classifications have been used in the preparation of landslide maps in the literature. Therefore, there is no standard in slope angle maps nor in the class range that is referenced when preparing them.

In this study, the class ranges and slope angle values of areas where landslides have occurred were determined from the literature, and of these, 40 landslides areas were selected in Turkey and their slope angle maps were created. These were evaluated according to the slope angle classes determined in the literature. The effects of the slope angle on the landslide were determined, and an understanding was gained of how important it was to be careful when determining the classification of the slope angle. When smaller class ranges were selected, different results were obtained. This showed that following parameter selection, the selection of the range of classes was vital in the preparation of landslide susceptibility maps.

\section{Introduction}

Slope, which is the expression of the rate of the vertical distance to the horizontal distance between two specified points with the tangent angle, has significant importance in terms of the formation, development, and susceptibility to landslides and has been defined as an input parameter in susceptibility studies by many researchers (Yomralıoğlu, 2000). In other words, slope is the measurement of surface steepness and it is measured as a degree. It has a range of $0-90^{\circ}$, where $0^{\circ}$ represents a horizontal area and $90^{\circ}$ represents a vertical area (YIImaz et al., 2012). In broader terms, slope is the angle between each surface section and horizontal reference point that measures the speed of change in height and that supports the flow of water and other materials in the direction of the slope in terms of the steepest drop in the slope for elevation (Dehnavi et al., 2017).

The slope is a derivative of the digital elevation model and is evaluated in the topographical parameter classification. In landslide susceptibility studies, the slopes at which landslide frequency is greatest are determined by classifying the slope. By superposing the relationship between the slope maps prepared in the specified classification intervals and the landslide inventory maps, the relationship between them is 
attempted to be specified. The slope classifications and the distributions (\%) and densities (\%) of landslides within the total areas for this are calculated (Çellek, 2013).

The literature comprises a consensus among researchers on the notion of the evaluation of the slope as an active parameter in the formation of landslides, and this parameter is commonly used in the evaluation of landslide susceptibility. Generally, the highest score has been given to the slope angle in landslide susceptibility analyses. A review conducted of 1500 studies in the literature determined that most researchers used the slope as an input parameter. Dağ (2007) reported that the slope was the most preferred parameter in 96 of 100 examined studies. Hasekioğulları (2011) stated that 109 of the 114 studies that they examined used the slope as an input parameter, and Çellek (2013) stated in a literature review that 281 of 293 studies used the slope. Süzen and Kaya (2014) stated that it was used as an input parameter in $97.90 \%$ of the studies they examined, while Budimir et al. (2015) found that it was used $95 \%$ of the time. Dölek and Avcı (2016) gave the heaviest weighted score to this parameter as $30 \%$ in the statistical method in their study, and Mehrotra et al. (1992) gave 35\% in theirs. Altın and Gökkaya (2006) showed the slope as the main parameter that triggered landslides in their study area. From this perspective, it is possible to say that the slope is the most influential and essential parameter over landslide susceptibility.

The choice of slope class ranges affects the results of the analysis. The important issue in the preparation of landslide maps is to choose the right parameter. The second issue is the determination of the correct class ranges for the selected parameter. For this purpose, an attempt will be made to determine the range of classes used in the literature. The case study prepared will be compared with the literature. As a result, it will be possible to say whether the slope is the most influential and essential parameter over landslide susceptibility. The slope angle values that occur in the landslide will be revealed with the correct class ranges.

\section{The Advantages And Disadvantages Of The Slope Angles Parameter}

The most important property of the slope is that it can easily be produced and analyzed from digital elevation model data through geographic information system programs and it can be easily mapped. The slope is an original factor that is used in slope instability, it creates the foundation for stability studies, and affects shear and normal tension on shear surfaces. The slope completely controls the movement of materials based on gravity. The slope or slope angles are directly influential in landslides and create the foundation for susceptibility studies. For this reason, this is a commonly used parameter in the evaluation of landslide susceptibility maps. On the other hand, Youssef et al. (2015) opined that no generalized decision could be made regarding the relationship between the slope angle and landslides.

The parameter classifications comprise the selection of the slope classification, the slope at which the landslide was encountered, the absence of a distinguishing parameter for each area, and its evaluation with other parameters. If we were to complement the prediction that landslide susceptibility decreases as 
the slope increases by using only the slope, the results would be largely incoherent. For this reason, other factors must not be ignored (Gökçeoğlu and Ercanoğlu, 2001), such as the soil, debris, types of rock in the study area, and materials occurring within the landslide.

In most studies, in evaluations regarding the use of the slope, the classification intervals belonging to the slope values have been considered differently. It is believed that this situation is unique to researchers and that classification intervals are determined by considering the intensities of landslides in the study area (Dağ, 2007). Some researchers believe that landslides occur between 30 and $40^{\circ}$, while others believe they occur above $25^{\circ}$, and still others believe they occur below $30^{\circ}$. As a result, differing viewpoints exist among researchers about the relationship between the slope and landslides, that it could vary regionally; hence the slopes of landslide-prone slopes must be evaluated statistically and interpreted (Hasekioğulları, 2011). Examples can be found within the literature in which landslide possibilities in all of the slope groups were close to one another in landslide susceptibility studies (Van Westen, 2003). Regardless of the extent to which it is thought that this is the most influential parameter in the formation of landslides, it demonstrates that the slope is not influential in every area.

\section{Effect Of The Slope Angle On Stability}

The slope aspect is one of the most important causal factors that affects slope stability (Kayastha, 2015). Because the component strength of gravity is the tendency of slope, this parameter tests the transportation of material by controlling the progression speed and motion distance. Increasing gravity and shear strength based on the growth of slope values facilitates the activation of materials by deteriorating the balance of the material. This causes an increase in landslide susceptibility. This is why the storage and dimension of the activated materials is related to this the slope (Wang et al., 2016). It is an empirical fact that a landslide incident can occur again in a region at which landslides have occurred previously (Taşoğlu et al., 2016).

The slope security factor is defined as the rate of shear stress for resistance strength (Alexakis et al., 2013). The main parameter of the balance analysis is the slope angle (Moradi and Rezaei, 2014). The slope is the original stability factor that influences shear and normal strength in shear surfaces (Anbalagan, 1992). A steep slope demonstrates how large the shear stress is and how low the security factor is for the slope (Nourani, et al., 2014). This is because as the slope increases, tangential stress also increases in the colluvium in residual or consolidated soil coverings, axial tension decreases (shearing strength increases in steep slopes), and stability deteriorates. Thus, with the increase of the slope, the block-creation potential of the material increases, and this leads to an increase in the weight of rock blocks. As a result, the slope does not only affect stress distribution within masses but also the magnitude of shear and normal stress on shear surfaces. Susceptibility deteriorates by increasing the shear strength in the soil because the slope value increases due to decreasing normal stress (Guo et al., 2014; Ullmann et al., 2017). The slope, gravity, and existing external elements create an internal strength and implement strength directly toward the center of the world along a vertical line. The slope determines how influential that strength is in ensuring the movement of the object; however, the steeper the slope, the 
stronger the gravitational strength that ensures the shear of the slope and allows the object to slide. For this reason, slope steepness can be defined as the risk factor tied to the most important soil factor that influences slope stability (Kornejady et al., 2017). The slope angle directly affects the stress distribution in the slope. Different slope angles do not only affect the residual stress magnitudes on existing shear surfaces or potential shear surfaces, but also determine the renewal and mechanism of deformation (Fan et al., 2017).

\section{Relationship Of The Slope With The Other Parameters}

The slope plays many important roles in the occurrence of landslides because many factors express the result of its combination effect (Rozos et al., 2010). The studies reviewed in the literature reported that the slope significantly, either directly or indirectly, affected the speed of the slope surface and subterranean water flow based on the gravity, soil water content, soil structure, erosion potential, and hydrological and geomorphological processes (Anbalagan, 1992; Wilson and Gallant, 2000). When evaluated together with the slope, these parameters become more important when certain conditions regarding climate condition severity, vegetation type and density, and geological formation discontinuity order and internal geometry are present (llia and Tsangaratos, 2016). It was revealed that the slope angle was more effective than elevation with the slope over landslide susceptibility. However, these assumptions can exhibit changes related to regional landslide properties and other parameters, as observed in the study areas.

\subsection{Relationship of the soil and the slope angle}

The slope controls hydraulic continuity and, therefore, the security factor for slopes (Saadatkhahi et al., 2014). Generally, slope stability is dependent on its interaction with material properties, such as the friction angle of the slope angle, permeability, cohesion, shear, strain, and normal stress (Acharya and Pathak, 2017), and landslides occur as a result of the interaction between the slope angle and these properties of the material (Youssef et al., 2015).

Groundwater affects the impermeable layer found above as a result of the effect of the slope and facilitates its motion by increasing its plasticity $(\mathrm{Avcl}, 2016)$. For example, Jaafari et al. (2015) reported that a steep slope in the working area close to the limits of stability mostly triggered the instability of surface formations when small changes occurred in the cohesion and porous water pressure. On the other hand, Rozos et al. (2010) classified the slope values according to the known upper-limit friction angles for silty soils.

The slope also affects stress distribution within masses (Dou et al., 2017). The slope security factor is defined as the rate of shear stress for resistance strength. This means that shear strength is a function of the slope angle. A steep slope demonstrates how large the shear stress is and how low the security factor is for the slope (Abedini et al., 2017; Chen et al., 2018). Conversely, low slopes are expected to have a more stable or lower shallow landslide frequency as a result of lower shearing stress (Guo et al., 2014).

\subsection{The Relationship of Hydrology and Slope Angle}


The slope is an important topographical factor that controls both the surface and underground hydrological status of the corrosive material in mountain land, and the hydrological continuity, groundwater, flow speed, moisture content, and security factor of slopes, as a result of the pour pressure, weathering surface, and surface flow speed (Balamurugan et al., 2016), all affect land stability (Saadatkhahi et al, 2014). While it is possible to study moisture content and pour pressure on a local scale, the regional hydraulic behavior must be observed with slope angle models on a larger scale (Mancini et al., 2015).

Critical slopes are evaluated under saturated conditions. This is because critical slope angles under dry side slope conditions have high values, and regions at this slope under field conditions exhibit less spatial distribution (Özşahin, 2015). Slides occur because of the steepness of the topographical slope and continuous canal erosion in the slope topography. Creep landslides can occur based on surface erosion and drainage at places where the slope values are high.

The slope triggers landslides on land in which clay layers that are saturated with water are common. The degree of the slope determines the redistribution of the surface materials and tension and the thickness of the surface water. Additionally, the slope determines the loose material and discontinuation and emptying of the groundwater (Lee and Min, 2001). In this context, hydrogeological and lithological conditions are present in landslides triggered by the slope. Indeed, Zhuang et al. (2015) reported that the slope in their study area affected the rates of infiltration and flow, and also the regolith layer and the thicknesses of the other units. Similarly, Avcı (2016) reported that landslides had a favorable relationship with lithological conditions and the excess amount of precipitation and groundwater.

\subsection{Relationship of lithology and the slope angle}

It is known that slope stability is largely related to the slope angle and material properties. The effect of the slope on landslide susceptibility varies based on the soil, debris, or rock type in the study area, and the type of materials occurring in the landslide (Zhuang et al., 2015; Avcl, 2016). In other words, while it is known that high-angle slopes are more susceptible to landslides, a general increase in susceptibility to initiate landslides is expected with the slope increasing up to the point at which the slope angle takes further steps for the creation of a layer of soil at an adequate thickness. The ground layer is generally expected to be important for the prediction of carrying regions preferred by steep ground (Süzen and Kaya, 2011; Moradi and Rezaei, 2014).

Slope values vary based on the lithological units in the study area. For example, slopes gain a state of incredible susceptibility to mass motions, like landslides, if the determined slopes occur together with decomposed and weak lithological rock units (Öztürk, 2002). Some researchers have emphasized that the loosening or density of the material with the slope in the study areas was the effect of landslides, and that the accumulation of loose material was directly related to the slope (Chen et al., 2013; Chalkias et al., 2014; Nourani et al., 2014; Goetz et al., 2015; Jebur et al., 2015; Öztürk et al., 2016; Pawluszek and Borkowski, 2017). For example, Çellek (2013) reported that, despite a low slope value in areas in which the zone that formed due to the decomposition of the flysch-type material was thick, it became more 
sensitive. As a result of the accumulation of soil in lower-slope topographies that formed due to the decomposition of flysch-type materials, landslides formed under the influence of the other parameters. Because steep slopes are mostly covered with durable slopes, landslides are not encountered at these segments. Sakkas et al. (2016) reported that geological formations with low slope values have lower susceptibility than formations with high values, and that a horizontal plane formation would never slide. Avcr (2016) related this to the favorability of encountering different mass motions at different slope values of $\left(0-45^{\circ}\right)$ in their study area and the height of the lithological conditions for landslide density between certain slope values $\left(5-15^{\circ}\right)$. Fan et al. $(2017)$ reported that landslides that occurred in the Silurian layer were at slopes with angles of $15-35^{\circ}$, which constituted approximately $82 \%$ of all landslides in the same layer. Although Pachauri and Panta (1992) demonstrated that the frequency of landslides was greater on steeper slopes $\left(>35^{\circ}\right)$, independent of lithology, Ercanoğlu et al. (2004) reported in their study area that steep slopes generally occurred in resistant limestone and quartzite, and that these units were not susceptible to landslides. Although Anbalgan (1992) provided the highest scores for areas with slope angles $>45^{\circ}$ in a landslide susceptibility study, Tangestani (2004) conversely encountered solid limestone and changed the classification of steep slopes for areas with slope angles > $45^{\circ}$. Fourniadis et al. (2007) performed a classification in which the threshold angles changed based on lithological competence, rather than on the slope angle, to estimate the critical angles in different lithologies in their susceptibility analysis. Hadji et al. (2016) emphasized that landslides began to be observed in marn clay formations located in the classification range of $5-15^{\circ}$, which were seen in the lower classifications, and intensified in the upper classifications. Nagarajan et al. (2000), in a study conducted in the Konkan region of India, determined that rockfall-type landslides occurred on steep slopes with a slope angle of $>80^{\circ}$ and that mudslide-type landslides occurred at slopes with a slope of $>$ $35^{\circ}$. They also reported that landslide susceptibility increased with the increase in slope. Dağ et al. (2011) reported in their study that slopes gained a state of incredible susceptibility to mass motions like landslides if the determined slopes occurred together with decomposed and weak lithological rock units, and that this was emphasized in similar studies conducted in the region.

\subsection{Relationship of climate and the slope angle}

The slope is related to parameters such as exposure to sunlight, wind, and rainfall, and this in turn affects landslides (Raja et al., 2017). It is generally possible to correlate the reasons for the concentration of landslides at certain slopes with certain slope and meteorological incidents, such as the general morphological slope of the field and the region in particular getting more general precipitation and/or sunlight. Slopes that receive heavy rainfall quickly reach saturation relative to slopes with inclinations other than a dominant inclination, and can cause the development of higher pore water pressures over time based on the capacity of permeation, which are controlled by many factors, such as topographic slopes, the soil type, permeability, porousness, moisture and organic substance contents, vegetation, and season in which the precipitation occurs. It is possible for the slopes in such an event to cause slopes that received more intense precipitation to be more susceptible to landslides (Ercanoğlu et al., 2004; Lee et al., 2004; Lee, 2005). 
Some steep natural slopes, such the bedrock mostras, are not susceptible to shallow landslides triggered by rain (Kritikos and Davies, 2014). The slope affects the amount of accumulated rain; hence, there is a longer duration of flooding on low slopes (Yüksel, 2007). Avcl (2016) related the prevalence of landslides in the $5-15^{\circ}$ group to the favorability of lithological conditions and the excess amount of precipitation and groundwater.

Wind speed is a variable related to the slope degree in sloped lands. Wind speed blowing up a slope is $10-30 \%$ less on the ground with a $6-20 \%$ slope when compared to that on flat ground (Yiğiter, 2008), which affects stability.

\subsection{Relationship of the aspect and the slope angle}

According to many researchers, the aspect and slope angle are more effective than elevation. This is why the steepness and direction of the slope can be clear variables that affect landslides (Tsangaratos and Benardos, 2014). The slope determines the intensity and scope of landslides because it determines the impression direction (Sadr et al., 2014). Özşahin and Kaymaz (2013) reported that the slope values of the areas in their study were highly susceptible to landslides to the south and east of the region. Additionally, they reported that because of the vegetation on the slopes toward the east, southeast, and northeast in the study area, the slope in the region had an important role in the development of mass motion. Avcl (2016) reported that the northern section of their study area was under the danger of landslides because the slope values were high. Champati et al. (2004) connected the absence of vegetation on slopes toward the north as the most important role in the weathering of stability in the evaluation of slopes on the steep slopes of the Himalayas. Based on this, it can be said that landslides develop according to the slope value and impression in different areas.

\subsection{Relationship of vegetation and the slope angle}

Avcl (2016) encountered expansive landslides on slopes at which the slope was high and the vegetation was sparse in their study area. Sadr (2014) reported in their study field that vegetation on high slopes played an important role in the development of fewer mass motions. Contrary to both studies, Alkevli (2015) did not encounter any landslide records for areas covered with dense vegetation and forested areas with a high slope angle of $60-80^{\circ}$. Yüksel (2007) reported that approximately $82 \%$ of landslides in their study area occurred at slope angles ranging between 10 and $30^{\circ}$, and that there was generally no vegetation or it was sparse.

\subsection{Relationship of erosion and the slope angle}

The slope has the potential to create erosion and it affects soil formation and many other processes (Wilson and Gallant, 2000). On slopes where the slope angle was very high, the soil material is expected to be unable to reach an efficient thickness value (at least 1-2 $\mathrm{m}$ ) because of erosion, and fewer landslides are expected because of the existence of solid rock materials. Conversely, landslides can occur because the zone of decomposition is thick at low slopes (Gökçeoğlu and Ercanoğlu, 2001; Bui et al., 2011; Elkadiri et al., 2014; Chen et al., 2015). 


\subsection{Relationship of seismicity and the slope angle}

Erdinç (2000) stated that some faults caused landslides that resulted in very steep slopes, while Avcl (2016) expressed that, by increasing the slope values in slopes and river valleys in which the slope dipslip faults intersected, landslides decreased in these areas.

Numerous studies regarding the landslides caused by the Wenchuan earthquake that took place in China in 2008 have been conducted, and it was reported that there were more landslides triggered by earthquakes and those that take place on certain slopes when compared to earthquakes that occurred as a result of the triggering of precipitation before earthquakes (Huang and Li, 2009; Tang et al., 2011). In their study, Tanoli et al. (2017) determined that $76 \%$ of landslides before earthquakes occurred at a slope angle between 20 and $50^{\circ}$, while $78 \%$ of landslides after earthquakes occurred at a slope angle between 30 and $80^{\circ}$. Yang et al. (2015) reported that the pressure slope for the slides caused by the Lushan earthquake was greater than that of the landslides triggered with precipitation before the earthquake.

\subsection{Relationship of the elevation, slope length, and slope angle}

A relationship is relevant between landslides, and the geological formation slope angle and the slope length. It is thought that with an increase in the height and slope length, slope instability also increases. For this reason, the relationships between landslides, and the geological formation slope angle and the slope length must be investigated.

The increase in height has a decreased effect on stability. It is thought that slopes that have the same slope value but are at different elevations are not the same in terms of hazard, and that the possibility that slopes with elevations that are greater than those of two slopes on the same slope become unstable and have greater hazard when compared to the others (Ahmed, 2014).

Hasekioğulları (2011) reported that landslide-prone areas were mostly located at elevation classifications between 250 and $500 \mathrm{~m}$, and determined that this was consistent with evaluations conducted for the slope. Hasekioğulları connected this to areas with high topographies in the study area being covered with steep slopes and to the formation of low topographical heights from soil materials, mostly the product of decomposition. Delikanlı (2010), in a logistic regression equation, determined that the likelihood of landslides increased with a higher slope elevation.

\section{Occurrence Of Landslides According To The Slope Angle}

Landslides are mostly seen at certain critical slope angles (Lee and Min, 2001; Öztürk, 2002; Rozos et al., 2010; Yılmaz et al., 2012; Özşahin, 2015; Avcı, 2016; Jayanthi et al., 2016; Laldintluanga et al.; 2016). Many researchers have asserted that an increase in the slope increases susceptibility to landslides (Pachauri and Pant, 1992; Gökçeoğlu and Ercanoğlu, 2001; Lee and Min, 2001; Öztürk, 2002; Lee, 2005; Özşahin, 2013; Özşahin and Kaymaz, 2013; Taşoğlu et al., 2016), while a portion of researchers have 
specified that landslides can also form on low slope angles (Ayenew and Barbieri, 2015). The general opinion is that landslides drop after a certain value, increasing with the slope value (Milewski et al., 2009; Chen et al., 2017; Hong et al., 2017). Conversely, Van Westen et al. (2003), in a landslide susceptibility evaluation study that they conducted in Italy, reported that the slope was not an effective parameter for the study area because the possibilities of landslides in all of the slope groups were close to one another.

Landslides are evaluated in different groups. In the literature, there have been intervals preferred by different researchers, while landslide slope values do not have definitive slope intervals. The most fundamental cause of this is that slope values are different for each land condition. Table 1 provides the slope values that were generally preferred in the literature review.

Table 1

The realized landslide slope values and groups in the literature

\begin{tabular}{|c|c|c|c|c|c|}
\hline \multirow{2}{*}{$\begin{array}{l}\text { Milewski et al } \\
\text { [220] }\end{array}$} & $0-10^{\circ}$ & $10-30^{\circ}$ & $>30^{\circ}$ & & \\
\hline & low slope & moderate slope & steep slope & & \\
\hline \multirow[t]{2}{*}{ Guo et al. [104] } & $0-10^{\circ}$ & $10-20^{\circ}$ & $20-30^{\circ}$ & $30-40^{\circ}$ & $>40^{\circ}$ \\
\hline & very soft & soft & moderate & steep & very steep \\
\hline \multirow[t]{2}{*}{ Kayastha [45] } & $<15^{\circ}$ & $15-25^{\circ}$ & $25-35^{\circ}$ & $35-45^{\circ}$ & $\left(>45^{\circ}\right.$ \\
\hline & flat & moderate slope & $\begin{array}{l}\text { rather moderate } \\
\text { slope }\end{array}$ & $\begin{array}{l}\text { steep } \\
\text { slope }\end{array}$ & $\begin{array}{l}\text { very steep } \\
\text { slope }\end{array}$ \\
\hline \multirow{2}{*}{$\begin{array}{l}\text { Ercanoğlu et al } \\
\text { [79] }\end{array}$} & $<6$ & 6 and 16 & $16-25$ & $25-33$ & $>33$ \\
\hline & $\begin{array}{l}\text { very soft } \\
\text { slopes }\end{array}$ & light slopes & $\begin{array}{l}\text { moderately } \\
\text { steep slopes }\end{array}$ & $\begin{array}{l}\text { steep } \\
\text { slopes }\end{array}$ & segments \\
\hline \multirow[t]{2}{*}{ Duo et al [111] } & $0^{\circ}-15^{\circ}$ & $15^{\circ}-30^{\circ}$ & $30^{\circ}-45^{\circ}$ & $>45^{\circ}$ & \\
\hline & soft slope & $\begin{array}{l}\text { moderately } \\
\text { steep slope }\end{array}$ & steep slope & cliff & \\
\hline \multirow[t]{2}{*}{ Özdemir [222] } & $0-2$ & $2-15^{\circ}$ & $15-25^{\circ}$ & $25-45^{\circ}$ & $>45(68)$ \\
\hline & $\begin{array}{l}\text { very small } \\
\text { slope (flat) }\end{array}$ & small slope & $\begin{array}{l}\text { light slope } \\
\text { (moderate) }\end{array}$ & steep & very steep \\
\hline \multirow{2}{*}{$\begin{array}{l}\text { Özşahin and } \\
\text { Kaymaz [188] }\end{array}$} & $0-3^{\circ}$ & $3-10^{\circ}$ & $10-20^{\circ}$ & $20-30^{\circ}$ & $>30$ \\
\hline & $\begin{array}{l}\text { very small } \\
\text { slope }\end{array}$ & small slope & moderate slope & $\begin{array}{l}\text { steep } \\
\text { slope }\end{array}$ & $\begin{array}{l}\text { very steep } \\
\text { slope }\end{array}$ \\
\hline
\end{tabular}

\section{Table 1. Realized landslide slope angles and groups in the literature.}

The literature evaluates landslide groups in classes 3,4 , and 5 . Values grouped as very low slope, low slope, moderate slope, high slope, and very high (steep) slope, based on the conditions of the studied 
land, were categorized based on low, moderate, and high slope values to be able to make generalizations in this study.

\subsection{Effect of high value $\left(>35^{\circ}\right)$ slope angles on landslides.}

The reason for the rarity of landslides in the very high slope range is that the width of the weathering zone is small and this reduces the susceptibility of landslides. It reduces normal stress and facilitates the activation of materials by increasing the shear stress of the soil, such as an increase in slope values and the strain of land shear. Landslides with high slope angles exceeding $45^{\circ}$ comprise sturdy rocks rather than weathered materials in the nature of ground, and these types of rocks are stable. However, any increase in the slope leads to an increase in the possibility of breaking away (Wilson and Gallant, 2000; Gökçeoğlu and Ercanoğlu, 2001; Lee and Min, 2001; Öztürk, 2002; Özşahin and Kaymaz, 2013; Lee, 2005; Sadr et al., 2014; Jayanthi et al., 2016; Laldintluanga et al., 2016).

Some researchers have stated that landslides were more common in steep areas when compared to moderate and soft-slope areas in their study areas (Rozos et al., 2010; Alexakis et al., 2013; Laldintluanga et al., 2016; Abedini et al., 2017). Nagarajan et al. (2000), in a study conducted in the Konkan region of India, determined that rockfall-type landslides occurred on steep slopes with a slope angle of $>80^{\circ}$, and that mudslide-type landslides occurred on slopes with a slope angle of $>35^{\circ}$. They also reported that landslide susceptibility increased with an increase in the slope.

Conversely, there are studies in which a sharp drop was seen in landslide intensity when slope angle reached $45^{\circ}$ (Tangestani, 2004; Jaafari et al., 2014; Chen et al., 2018). Although Chen et al. (2015) observed in their study that sloped fractures on high-angled slopes were more common than on low angle slopes, they stated that the frequency of landslides did not decrease because the high slope transitions could not support the accumulation of soil above a certain threshold. Similarly, Gökçeoğlu and Ercanoğlu (2001) reported that, in order to see landslides in ground soil, the thickness of the present soil had to be at least 1-2 $\mathrm{m}$ and, most of the time, it would be difficult to see landslide activity because it was not possible to reach these thickness values. Jayanthi et al. (2016) did not encounter any landslide in areas at slope angles $>25^{\circ}$ because vegetation is unimportant in the very high slope category. Additionally, no rockfall of any kind was encountered in the research area despite the ability of rockfalls to form at great heights.

\subsection{Effect of moderate value $\left(15-35^{\circ}\right)$ slope angles on landslides}

This situation is valid for slopes with moderate slope angles. The increasing angles in these types of slopes negatively affects the susceptibility of slopes because it will increase the shear stress of the soil. Most researchers have reported that most landslides in their area of research formed on slopes with angles ranging from 15 to $35^{\circ}$ (Lee and Min, 2001; Ercanoğlu et al., 2004; Hong et al., 2017; Pham et al., 2017). 
However, the literature contains research that has claimed the opposite of this. Erener and Lacasse (2007) did not report a relationship regarding landslides at locations where the slope angle was $>15^{\circ}$. Chau and Chan (2005) reported that landslides developed at higher angles, despite the fact that slopes with angles of $25-30^{\circ}$ are more suitable for landslides.

\subsection{Effect of low value $\left(<15^{\circ}\right)$ slope angles on landslides}

Because slopes with high angles form from rock units and the thickness of the weathering zone increases in low-angle slopes, it is thought that slopes with this slope angle are more susceptible to landslides. There are studies that have demonstrated that landslides occur at low slope angles (Milewski et al., 2009; Yılmaz et al., 2012).

There are studies regarding landslides that have occurred on slopes with low slope angles, below $15^{\circ}$, in the literature. Conversely, there are studies that have claimed that, because shear stress would be lower in areas with much lower slope angles, landslides would not form at these slope angles, and that they encountered few or no landslides in areas with slope angles below $15^{\circ}$ (Lee and Min, 2001; Ercanoğlu et al., 2004; Dağ, 2007; Pham et al., 2017).

\subsection{Classification of slope angles}

An important issue is the classification of the slope factor. Landslide susceptibility evaluations report which slope classification intervals landslides are concentrated on by classifying different degrees of the slope to determine the slopes at which the landslide frequency is the greatest. There is no slope classification used as a standard interval with regards to the slope angle. In most studies, the classification intervals belonging to the slope angles are taken differently. Generally, researchers prefer automatic classification because it is a fast and easy solution. On the other hand, because each study has different intervals according to the properties of the land, researchers can use their own classifications based on the land conditions and the concentrations of landslides in the research area (Biçer-Tetik, 2017). For this purpose, slope angle maps are separated into groups (e.g., $0-5^{\circ}, 5-10^{\circ}, 10-$ $15^{\circ}$, and $>15^{\circ}$ ). These groups can later be reclassified as low slope, medium slope, and high slope. Other than this, there have also been other classifications created in the literature. One of these is the natural fracture optimization technique by Jenks (1967). Some researchers have observed that this classification was effective in describing information content-specific to the soil regarding the vulnerability of the slope and landslides, and used it in their studies (Balamurugan et al., 2016). Most researchers have applied equal intervals to determine the lower classifications (Yılmaz et al., 2012). Some have used these classifications again at $5^{\circ}$ intervals (Özşahin, 2013; Chen et al., 2015). Differently, there have been researchers who used certain standard classification intervals. For example, while Özşahin and Kaymaz (2013) noted the slope classifications made by Mcdonald (1975) in the classification of slope angles in their study area, Özşahin (2013) examined the effect of the slope according to the slope classification explained by Bijukchhen et al. (2013). Özşahin (2015) reported the effect of the slope in the examination field in another study according to the slope classification explained by Varnes (1976). Constantin et al. (2011) made classifications according to the field observations of Balteanu (2010). Mahanta et al. (2016) 
used the BIS classification, which defines the slope map and slope classifications according to the formation frequency of the specific slope angles.

The evaluation of the reviewed studies was done in an attempt to determine the slope angle intervals in which the study areas were generally found (Fig. 1), how many classes a slope could be divided into (Fig. 2), at which slope angles landslides were observed (Fig. 3), and at which slope angles were no landslides observed (Fig. 4).

From the literature, 50 study areas were randomly selected and drawn (Fig. 1). It was seen that most of the studies were conducted in areas with a slope angle of $0-90^{\circ}$ and following that, were areas with a slope angle of $0-70^{\circ}$.

\section{Figure 1. Slope interval graphs for 50 areas at which landslide research was conducted.}

The classification intervals used in the studies varied. The literature research provided the slope classification intervals prepared from randomly selected studies. Classification interval graphics were drawn for 125 selected studies and given in Fig. 2.

Figure 2. Graphs for the classification groups of the selected studies.

As seen from Fig. 2, the most frequently preferred classification intervals in the literature are 5 and 6 . It can also be seen that the classification interval selection in the literature offers a wide array, from 3 to $20^{\circ}$. The classification interval selection varies based on the slope angles and mass motion type of the studied area.

The slope intervals at which most of the landslides occurred were separated into 3 classifications, and graphs were drawn and are presented in Fig. 3.

Figure 3. Realized landslide slope interval graphics.

The literature mentioned the slope intervals at which landslides occurred or rarely occurred and as can be seen in Fig. 3, most of the landslides occurred at slope angles below $30^{\circ}$.

Graphs for slope angles at which no landslides occurred (non-landslide areas) were also prepared (Fig. 4). These were evaluated in 3 groups, as $<15^{\circ}, 15-45^{\circ}$, and $>45^{\circ}$. It can be seen that there was no increase in the number of landslides encountered on slopes with angles below $15^{\circ}$ or above $45^{\circ}$.

Figure 4. Slope angle intervals at which there were non-landslides or landslides rarely occurred.

\section{Methods}

A comprehensive literature review has shown that the likelihood of landslides is most affected by the slope angle and its classifications. It is understood that landslides occur at certain slope angles in certain areas. Their lithological origin is the main reason for these differences. Moreover, whether the landslide 
occurs on rock or soil ground is also affected by the angle of the slope; hence, landslides are expected at low slope angles on soils and at higher slope angles in rocky areas.

To strengthen the literature research, training is necessary for the specific researched landslide distribution areas selected from Turkey on the impact of the slope angle and its classes.

For this purpose, class ranges consisting of $3,5,8,10,15,18$, and $20^{\circ}$ were prepared for all of the selected areas in Turkey (Table 2). According to the literature, the most preferred angles were set for 7 class ranges. Exact slope angles for use in the study areas could not be found in the literature, but it was possible to make an estimate. However, it may be possible to find class range options for a similar study area or a previously studied area. The reason for the analysis in each class range was to try to understand how effective the determination of the slope class range was in preparing the slope angle map. In some studies, the selection of class ranges was considered to be insignificant and automatic class ranges provided by computer programs were used.

Table 2

Researchers and the ground slope intervals with which they work, according to the selected studies

\begin{tabular}{|llll|}
\hline Aralık & En yüksek & İkinci en yüksek & Toplam heyelanlı \\
\hline 3 & $9-12$ & $6-9$ & $\sim 500 \mathrm{~m}^{2}$ \\
\hline 5 & $5-10$ & $10-15$ & $\sim 700 \mathrm{~m}^{2}$ \\
\hline 8 & $8-16$ & $0-8$ & $\sim 900 \mathrm{~m}^{2}$ \\
\hline 10 & $0-10$ & $10-20$ & $\sim 1100 \mathrm{~m}^{2}$ \\
15 & $0-15$ & & $\sim 800 \mathrm{~m}^{2}$ \\
\hline 20 & $0-20$ & & $\sim 900 \mathrm{~m}^{2}$ \\
\hline
\end{tabular}


Table 2

Slope intervals, which are the most landslide according to the total areas

\begin{tabular}{|llllllll|}
\hline Class & 3 & 5 & 8 & 10 & 15 & 18 & 20 \\
\hline 1 & $9-12^{0}$ & $5-10^{0}$ & $8-16^{0}$ & $10-20^{0}$ & $0-15^{0}$ & $0-18^{0}$ & $0-20^{0}$ \\
\hline 2 & $6-9^{0}$ & $10-15^{0}$ & $0-8^{0}$ & $0-10^{0}$ & $15-30^{0}$ & $18-36^{0}$ & $20-40^{0}$ \\
\hline 3 & $12-15^{0}$ & $15-20^{0}$ & $16-24$ & $20-30^{0}$ & $15-45^{0}$ & & \\
\hline 5 & $3-6^{0}$ & $0-5^{0}$ & $24-32^{0}$ & $30-40^{0}$ & & \\
\hline 6 & $15-18^{0}$ & $20-25^{0}$ & & & & \\
\hline 7 & $18-21^{0}$ & $25-30^{0}$ & & & & & \\
\hline 8 & $21-24^{0}$ & $30-35^{0}$ & & & & & \\
\hline 9 & $0-3^{0}$ & & & & & & \\
\hline 10 & $24-27^{0}$ & & & & & & \\
\hline
\end{tabular}

Table 2. Slope angle class ranges for areas where landslides occurred most often.

In Table 2, the slope angle ranges were determined for the studied landslides areas, and how important the class range selection is, was summarized therein. Different angle ranges actually give the code of the class ranges that will lead to the correct result. When each group was examined, the intersection angle could be found. For example, in the classification prepared with the class range of $3^{\circ}$, there were landslides in 10 groups, while in the group prepared for class ranges of $20^{\circ}$ and $18^{\circ}$, only 2 groups were seen. Based on this, Table 3 was prepared and the total landslide distribution was calculated according to each class range. In Table 3, the $18^{\circ}$ interval angle was not included in the calculation. The reason for this was that the slope ranges were sufficiently close to each other already. A similar situation was found at 8 and $10^{\circ}$. These were very close values. These 2 values were included in the calculation

Table 3. Landslide distributions according to the slope angle classes.

As can be seen from Table 3 , the $3^{\circ}$ classification provided the most sensitive angles. Based on the table, the range in which the landslide distribution was most intense was determined as $6-12^{\circ}$. The inclusion of landslide distribution in the calculation also helped to form this conclusion. Finally, the graphics were prepared for 6 class values (Fig. 5).

Figure 5. Landslide distributions in all of the areas according to the slope classes. 
When Fig. 5 is examined, it can be seen that the second goal of the study was reached, wherein both the slope and its classes had a great impact on the occurrence of landslides. And finally, the landslide distribution gradually decreased when the slope angle exceeded $40^{\circ}$ in all of the areas examined in the study.

\section{Results And Discussion}

The literature research has shown that each landslide susceptibility study has had unique features. Each study area has had its own character, and the parameters used should be selected according to those study areas. However, almost all of the studies hold a consensus that the most significant parameter is the slope angle. According to the literature, in general, the classifications generated at intervals of $5^{\circ}$ were ideal. In addition, the visuals of the parameter maps prepared at this slope angle were also beautiful. According to the literature, automatic classification still provides the best results visually.

In the literature studies, the effect of the slope angle on landslides with other parameters was also investigated. One of the parameters that increased the effect of the slope angle was elevation, and another was lithology. Especially at high altitudes rocky areas, rockfall is expected on high slopes, while lower elevation angles are expected for landslides at lower elevations. According to the literature, landslide occurrences were investigated according to the slope classes. It was observed that landslides were also encountered within the different slope groups. Landslides can occur below 5 or above to $70^{\circ}$. One of the biggest reasons for these angle differences is lithology. This affects the type of mass movement. As a result, flow and rockfall occur at very different slope angles. This is the main reason why slope class ranges cannot be standardized among researchers, which is also the same in non-landslide areas where no landslides have occurred. For example, some researchers have stated that they did not expect landslides to occur at slope angles above $45^{\circ}$, while others claimed that they did not expect landslides to occur at slope angles below this. In addition, the researchers had aimed to keep the number of groups created in their studies within certain values. It was observed that attempts were made to avoid errors in their analyses by using fewer groups. To better understand the effects of the slope angle and its classifications on landslides the selected from Turkey, the landslide distributions were analyzed. The selected areas had the same soil features, but different types of lithology.

In consideration of the research literature, 6 groups were selected, with the smallest range angle as $3^{\circ}$ and the largest as $20^{\circ}$. According to the class levels, in low-range classifications, such as $3,5,8$, and $10^{\circ}$, landslide distribution increased as the slope angle increased and after reaching the peak angle, it decreased gradually. However, in classifications created with 15 and $20^{\circ}$, it ended with a sharp decrease after the peak angle. In the same area, the classification maps for 5 and $15^{\circ}$ showed different graphic distributions. A gradual increase was observed in the graphics prepared of a landslide with a slope angle of $5^{\circ}$ and there was a gradual decrease observed in the graphics prepared with a slope angle of $15^{\circ}$. In all of the areas, the most common landslides occurred on slopes with slope angles that ranged between 6 and $12^{\circ}$. In the literature, this indicated that the selected angles of 5 and $10^{\circ}$ were mostly incorrect. When the slope angle exceeded $21^{\circ}$, the landslide distribution decreased to $50 \mathrm{~m}^{2}$ and after this, the landslide 
distribution decreased as the slope angle increased. Similarly, when a lower slope angle was observed between 0 and $3^{\circ}$, a landslide distribution close to $50 \mathrm{~m}^{2}$ was also observed. Landslide distributions on the soil responded positively for low slope angles. According to the literature regarding soil type, landslides are not frequently encountered at slope angles above $30^{\circ}$.

When evaluated visually, in the literature, automatic classification made a more accurate representation on the map and it was determined that the most preferred range, at $5^{\circ}$, provided better results than the others. In other words, while preparing the slope map in the landslide region, it is recommended to use the location as meticulously as it would be used in an automatic map for visual inspection, even if the slope angle is is $6-12^{\circ}$.

As a result, this article attempted to provide a basis for landslide susceptibility maps. The slope angle was the most used parameter in the literature. Determination of the slope classes was also the most discussed topic. Herein, it was aimed to provide the effect of the slope angle on landslides, its use with other parameters, and the slope class ranges. With this study, a preliminary study was made among researchers using the slope angle and its classification.

\section{Conclusions (Or Summary)}

The literature showed that different class ranges, from 3 to $20^{\circ}$, have been used. The most preferred classification groups were 5 and 6 . It was aimed to prepare the current study in accordance with the literature. Slope maps were also created with the automatic classes provided by the program based on the literature research and were not included in the calculations.

The automatic classification provided the best visual results when evaluated with the other angles of the slope class ranges. The landslide distribution increased up to a certain point according to the slope angles. Different results were obtained with different classifications used in the same area. There was an increase in visual up to the peak angle in the graphics of the classifications prepared at $3^{\circ}$ degree intervals, whereas the classifications prepared at $20^{\circ}$ intervals were very different.

As a result, this study attempted to focus on the issue of slope classifications, which are open to discussion in the literature. A list was prepared here of the sensitive slope angles for landslides. This landslide susceptibility study is a reference for researchers This study attempted to provide insight for new researches, as selecting the smallest possible slope class made the results even more precise.

The high or low slope angles in the study areas did not change the observed slope class ranges. Landslides occurred more intensely between 0 and $24^{\circ}$. The study results were similar to those in the literature. However, landslides have occurred in different class ranges in the literature. The main reason for this difference was the effect of the type of landslide and the other parameters used.

Herein, it was concluded that a slope angle map could be created in several stages and the correct results could be achieved. Other classifications should be checked before making a general statement in the field 
and it is recommended to classify the landslide according to the slope angles in this way.

When the total landslide distribution was examined for the same areas, it was observed that the range angles should be chosen as narrowly as possible. It was concluded that a definite result could be obtained by making a second classification under necessary conditions. This showed that the smallest possible slope class for a study area should be selected, and the slope groups that have been prepared by researchers in studies within the literature should be reviewed and used as classification slope maps to provide the best results.

\section{Abbreviations}

MTA

General Directorate of Mineral Research and Exploration

\section{Declarations}

\section{Availability of data and material}

The data sets of this article have been prepared by me and uploaded to your journal's system as a supplement file.

\section{Competing interests}

The authors declare that they have no competing interest.

\section{Funding}

This work was supported by Kırşehir Ahi Evran University BAP Grant Number MMF.A4.18.017.

\section{Authors' contributions}

I proposed the topic, conceived and designed the study and carried out the experimental study. Also, I analyzed the data and helped in their interpretation and collaborated with the corresponding author in the construction of manuscript. I read and approved the final manuscript.

\section{Authors' information}

The whole article has been prepared by me.

\section{Acknowledgements}


I thank Kırşehir Ahi Evran University for their support in funding the maps used in the study.

\section{References}

1. Abedini M, Ghasemyan B, Mogaddam MH (2017) Landslide susceptibility mapping in Bijar City, Kurdistan Province, Iran: A comparative study by logistic regression and AHP models. Environ Earth Sci 76:308. doi:10.1007/s1266501765023

2. Acharya S, Pathak D (2017) Landslide hazard assessment between Besi Sahar and Tal area in Marsyangdi River Basin, West Nepal. IJARSG 5(1):29-38

3. Ahmed B (2014) Landslide susceptibility mapping using multi-criteria evaluation techniques in Chittagong Metropolitan Area, Bangladesh. Landslides 12(6):1077-1095

4. $10.1007 /$ s11069-013-0770-3

Alexakis DD, Agapiou A, Tzouvaras M, Themistocleous K, Neocleous K, Michaelides S, Hadjimitsis DG (2013) Integrated use of GIS and remote sensing for monitoring landslides in transportation pavements: The case study of Paphos area in Cyprus. Nat. Hazards, doi.org/10.1007/s11069-0130770-3

5. Alkevli T (2015) An investigation on the use of sampling strategies and some decision tree algorithms in production of landslide susceptibility maps, Doctorate Thesis (in Turkish), Turkey, Hacettepe University

6. Altın A, Gökkaya H, Nalbant M (2006) The effect of cutting speed in machine parameters on the Machinability of inconel 718 superalloys. J Fac Eng Archit Gazi 21(3):581-586. doi.org/10.1016/j.matdes.2006.09.004

7. Anbalagan R (1992) Landslide hazard evaluation and zonation mapping in mountainous terrain. Eng Geol 32:269-277. doi.org/10.1016/0013-7952(92)90053-2

8. Avcı V (2016) Analysis of landslide succeptibility of Manav Stream Basin (Bingöl). J Int Soc Res 9:42-49. doi.org/10.17719/jisr.20164216199

9. Balamurugan G, Ramesh V, Touthang M (2016) Landslide susceptibility zonation mapping using frequency ratio and fuzzy gamma operator models in part of NH-39, Manipur, India, Nat Hazards, doi.org/10.1186/s40677-014-0009-y 84, 465-488

10. Balteanu D, Chendes V, Sima M, Enciu P (2010) A country-wide spatial assessment of landslide susceptibility in Romania, Geomorphology, 124:102-112

11. doi.org/10.1016/j.geomorph.2010.03.005

12. Biçer-Tetik Ç (2017) A semi-quantitative evaluation of landslide risk mapping, Doctorate Thesis (in Turkish), Hacettepe University, Turkey

13. Bijukchhen SM, Kayastha P, Dhital MR (2013) A comparative evaluation of heuristic and bivariate statistical modelling for landslide susceptibility mappings in Ghurmi-Dhad Khola, East Nepal. Arabian J Geosci 6:2727-2743. doi.org/10.1007/s12517-012-0569-7 
14. Budimir MEA, Atkinson PM, Lewis HG (2015) A systematic review of landslide probability mapping using logistic regression. Landslides 12:419-436. doi.org/10.1007/s10346-014-0550-5, 2

15. Bui DT, Pradhan B, Lofman O, Revhaug I, Dick OB (2011) Landslide susceptibility mapping at Hoa Binh province (Vietnam) using an adaptive neuro fuzzy inference system and GIS. J Comp Geosci 45:199-211. doi.org/10.1016/j.cageo.2011.10.031

16. Çellek S (2013) Landslide susceptibility analysis of Sinop-Gerze region, Doctora Thesis (in Turkish) KTU, Turkey

17. Chalkias C, Ferentinou M, Polykretis C (2014) GIS-based landslide susceptibility mapping on the Peloponnese Peninsula, Greece Geosci., 4:176-190, doi.org/10.3390/geosciences4030176

18. Champati ray PK (2004) GIS based landslide modelling. In: Nagarajan R (ed) Landslide disaster: Assessment and monitoring. Anmol Publications, New Delhi, pp 81-96

19. Chau KT, Chan JE (2005) Regional bias of landslide data in generating susceptibility maps using logistic regression: Case of Hong Kong Island. Landslides 2:280-290. doi.org/10.1016/j.proeng.2018.01.135

20. Chen CW, Saito H, Oguchi T (2015) Rainfall intensity-duration conditions for mass movements in Taiwan. Prog Earth Planet Sci 2:1-13. doi.org/10.1186/s40645-015-0049-2

21. Chen W, Pourghasemi HR, Kornejady A, Xie X (2018) GIS-based landslide susceptibility evaluation using certainty factor and index of entropy ensembled with alternating decision tree models, In book: Natural Hazards GIS-Based Spatial Modeling Using Data Mining Techniques. Adv. Nat. Technol. Hazards Res., 48

22. Chen W, Pourghasemi HR, Kornejady A, Zhang N (2017) Landslide spatial modeling: Introducing new ensembles of ANN, MaxEnt, and SVM machine learning techniques. Geoderma 305:314-327. doi.org/doi.org/10.1016/j.geoderma.2017.06.020

23. Constantin M, Bednarik M, Jurchescu MC, Vlaicu M (2011) Landslide susceptibility assessment using the bivariate statistical analysis and the index of entropy in the Sibiciu Basin (Romania). Environ Earth Sci 63(2):397-406. doi.org/10.1007/s12665-010-0724

24. Dağ S, Bulut F, Alemdağ S, Kaya A (2011) A general evaluation of the methods and parameters used in the production of landslide sensitivity maps. Gümüşhane University Journal of Institute of Science (in Turkish) 1(2):151-176

25. Dağ S (2007) Landslide susceptibility analysis of Çayeli (Rize) and its surranding by statistical methods, Doctora Thesis (in Turkish KTU Turkey

26. Dehnavi A, Aghdam IN, Pradhan B, Varzandeh MHM (2015) A new hybrid model using step-wise weight assessment ratio analysis (SWARA) technique and adaptive neuro-fuzzy inference system (ANFIS) for regional landslide hazard assessment in Iran, Catena, 135:122-148, doi.org/10.1016/j.catena.2015.07.020

27. Delikanlı M (2010) Landslide Susceptibility Investigation of Yaka (Gelendost, Isparta) Region with Geographic Information System, Master Thesis, Selçuk University Turkey 
28. Dölek I, Avcı V (2016) Determination of areas with landslide susceptibility in Arguvan district (Malatya province) and its surrounding by multi-criteria decision analysis method (MDAM). J Acad Soc Sci 4(33):106-129

29. Dou J, Yamagishi H, Xu Y, Zhu Z, Yunus AP (2017) Characteristics of the torrential rainfall--nduced shallow landslides by typhoon bilis, in July 2006, using remote sensing and GIS, In book: GIS Landslide Publisher: Springer Japan

30. Elkadiri R, Sultan M, Youssef AM, Elbayoumi T, Chase R, Bulkhi AB, Al-Katheeri MM (2014) A remote sensing-based approach for debris-flow susceptibility assessment using artificial neural networks and logistic regression modeling. IEEE J Sel Top Appl Earth Obs Remote Sens 7(12):4818-4835. doi.org/10.1109/JSTARS.2014.2337273

31. Ercanoğlu M, Gökceoğlu C, Van Asch ThWJ (2004) Landslide susceptibility zoning north of Yenice (NW Turkey) by multivariate statistical techniques. Nat Hazards 32:1-23.

doi.org/10.1023/B:NHAZ.0000026786.85589.4a

32. Erener A, Lacasse S (2007) Landslide susceptibility mapping using GIS, TMMOB Chamber of Survey and Cadastre Engineers National Geographic Information Systems Congress KTU Turkey

33. Erinç S (2000) Geomorfologi I. (in Turkish), Book, Istanbul Pub

34. Fan JR, Zhang XY, Su FH, Ge YG, Tarolli P, Yang ZY, Zeng C, Zeng Z (2017) Geometrical feature analysis and disaster assessment of the Xinmo landslide based on remote sensing data. J Mt Sci 14(9):1677-1688. doi.org/10.1007/s10346-017-0927-3

35. Fourniadis IG, Liu JG, Mason PJ (2007) Landslide hazard assessment in the Three Gorges area, China, using ASTER imagery: Wushan-Badong, Geomorphol., 84:126-144, doi.org/10.1016/j.geomorph.2006.07.020

36. Goetz JN, Brenning A, Petschko H, Leopold P (2015) Evaluating machine learning and statistical prediction techniques for landslide susceptibility modeling. Comput Geosci 81:1-11. doi.org/10.1016/j.cageo.2015.04.007

37. Gökçeoğlu C, Ercanoğlu M (2001) Uncertainties on the parameters employed in preparation of landslide susceptibility maps. Bulletin of Earth Sciences Application Research Centre of Hacettepe University 23:189-206

38. Guo D, Hamada M, He C, Wang Y, Zou Y (2014) An empirical model for landslide travel distance prediction in Wenchuan earthquake area. Landslides 11:281-291. doi.org/10.1007/s10346-0130444-y

39. Hadji R, Chouabi A, Gadri L, Rais K, Hamed Y, Boumazbeur A (2016) Application of linear indexing model and GIS techniques for the slope movement susceptibility modeling in Bousselam upstream basin Northeast Algeria. Arabian J Geosci 9(3):192. doi.org/10.1007/s12517-015-2169-9

40. Hasekioğulları GD (2011) Assessment of parameter effects in producing landslide susceptibility maps. Master Thesis (in Turkish) Hacettepe University, Turkey

41. Hong H, Ilia I, Tsangaratos P, Chen W, Xu C (2017) A hybrid fuzzy weight of evidence method in landslide susceptibility analysis on the Wuyuan area. China Geomorphology 290:1-16. 
doi.org/10.1016/j.geomorph.2017.04.002

42. Huang R, Li W (2009) Development and distribution of geohazards triggered by the 5.12 Wenchuan Earthquake in China, Sci. China Ser. E-Technol Sci 52:810-819. doi.org/10.1007/s11431-009-0117-1

43. Jaafari A, Najafi A, Rezaeian J, Sattarian A (2015) Modeling erosion and sediment delivery from unpaved roads in the north mountainous forest of Iran. Int J Geomath 6(2):343-343. doi.org/10.1007/s13137-014-0062-4

44. Jayanthi J, Raj TN, Gandhi MS (2016) Identification of landslide-prone areas using remote sensing techniques in Sillahalla watershed, Nilgiris District, Tamilnadu, India. Int J Eng Technol 3(6):19471952

45. Jebur MN, Pradhan B, Tehrany MS (2015) Manifestation of LiDAR derived parameters in spatial prediction of landslides using a novel ensemble evidential belief functions and support vector machine models in GIS. IEEE J Sel Top Appl Earth Obs Remote Sens 8:674-689. doi.org/10.1109/JSTARS.2014.2341276

46. Jenks GF (1967) The data model concept in statistical mapping IntYear. Book Cartogr 7:186-190

47. Kayastha $P(2015)$ Landslide Susceptibility mapping and factor effect analysis using frequency ratio in a catchment scale: a case study from Garuwa sub-basin, East Nepal. Arabian J Geosci 8(10):8601-8613. doi.org/10.1007/s12517-015-1831-6

48. Kornejady A, Ownegh M, Bahremand A (2017) Landslide susceptibility assessment using maximum entropy model with two different data sampling methods. Catena 152:144-162. doi.org/10.1016/j.catena.2017.01.010

49. Kritikos T, Davies T (2014) Assessment of rainfall-generated shallow landslide/debris-flow susceptibility and runout using a GIS-based approach: Application to western Southern Alps of New Zealand. Landslides 12(6):1051-1075. doi.org/10.1007/s10346-014-0533-6

50. Laldintluanga ErH, Lalbiakmawia F, Lalbiaknungi ErR (2016) Landslide hazard zonation along state highway between Aizawl City and Aibawk Town, Mizoram, India Using Geospatial Techniques. Int. J. Eng. Sci. Res. Technology 5 (2)

51. Lee S, Choi J, Min K (2004) Probabilistic landslide hazard mapping using GIS and remote sensing data at Boun, Korea. Int J Remote Sens 25(11):2037-2052.

doi.org/10.1080/01431160310001618734

52. Lee S, Min K (2001) Statistical analyses of landslide susceptibility at Yongin. Korea Environmental Geology 40(9):1095-1113. doi.org/10.1007/s002540100310

53. Lee S (2005) Application of logistic regression model and its validation for landslide susceptibility mapping using GIS and remote sensing data journals. Int J Remote Sens 26:1477-1491. doi.org/10.1080/01431160412331331012 24

54. Mancini F, Capra A, Castagnetti C, Ceppi C, Bertacchini E, Rivola R (2015) Contribution of geomatics engineering and VGI within the landslide risk assessment procedures, Conference: International Conference on Computational Science and its Applications 
55. McDonald HC, Grubbs RC (1975) Landsat imagery analysis: an aid for predicting landslide prone areas for highway construction, Proceeding NASA Earth Resource Symposium, 1b, NASA, National Aeronautics and Space Administration, Washington D.C., 769-778

56. Mehrotra R, Namuduri K, Ranganathan N (1992) Gabor filter-based edge detection. Pattern Recogn 25(12):1479-1494. doi.org/10.1016/0031-3203(92)90121-X

57. Moradi S, Rezaei MA (2014) GIS-based comparative study of the analytic hierarchy process, bivariate statistics and frequency ratio methods for landslide susceptibility mapping in part of the Tehran metropolis. Iran J Geope 4(1):45-61. doi.org/10.22059/jgeope.2014.51191

58. Nagarajan R, Roy A, Vinod, Kumar R, Mukherjee A, Khire MV (2000) Landslide hazard susceptibility mapping based on terrain and climatic factors for tropical monsoon regions. Bull Eng Geol Environ 58:275-287. doi.org/10.1007/s100649900032

59. Nourani V, Pradhan B, Ghaffari H, Sharifi SS (2014) Landslide susceptibility mapping at Zonouz Plain, Iran using genetic programming and comparison with frequency ratio, logistic regression and artificial neural network models. Nat Hazards 71:523-547. doi.org/10.1007/s11069-013-0932-3

60. Özdemir A (2009) Landslide susceptibility mapping of vicinity of Yaka Landslide (Gelendost, Turkey) using conditional probability approach in GIS. Environ Geol 57:1675-1686. doi.org/10.1007/s00254008-1449-z

61. Özşahin E, Kaymaz ÇK (2013) Landslide susceptibility analysis of Camili (Macahel) Biosphere Reserve Area (Artvin, NE Turkey). Turkish Studies - International Periodical For The Languages, Literature and History of Turkish or Turkic. Turkey 8(3):471-493.

doi.org/10.7827/TurkishStudies.4260

62. Özşahin E (2015) Landslide susceptibility analysis by geographical information systems: the case of Ganos Mount (Tekirdağ) (in Turkish). Electron J Map Technol, doi.org/10.15659/hartek.15.04.68, 7, $1,47-63$

63. Öztürk M, Gökyer E, Sezgin M (2016) Seen at Amasra-Bartın-Safranbolu Highway Slopes Landscape Repair Against Landslides Evaluation of Their Work (in Turkish). National Landslide Symposium, Turkey, 635-646

64. Pachauri AK, Pant M (1992) Landslide hazard mapping based on geological attributes. Eng Geol 32:81-100. doi.org/10.1016/0013-7952(92)90020-Y

65. Pawluszek K, Borkowski A (2017) Impact of DEM-derived factors and analytical hierarchy process on landslide susceptibility mapping in the region of Rożnów Lake, Poland. Nat Hazards 86(2):919-952. doi.org/10.1007/s11069-016-2725-y

66. Pham BT, Bui DT, Prakash I, Dholakia MB (2017) Hybrid integration of multilayer perceptron neural networks and machine learning ensembles for landslide susceptibility assessment at Himalayan area (India) using GIS. Catena 149:52-63. htdoi.org/10.1016/j.catena.2016.09.007

67. Raja NB, Çiçek I, Türkoğlu N, Aydin O, Kawasaki A (2017) Landslide susceptibility mapping of the Sera River Basin using logistic regression model. Nat Hazards 85:1323-1346.

doi.org/10.1007/s11069-016-2591-7

Page 23/28 
68. Rozos D, Bathrellos GD, Skilodimou HD (2010) Landslide susceptibility mapping of the northeastern part of Achaia Prefecture using Analytical Hierarchical Process and GIS techniques. Bull. Geol. Soc. Greece, Proceedings of the 12th International Congress, Patras may, XLIII, 3:1637-1646

69. Saadatkhahi N, Kassimi A, Lee ML (2014) Qualitative and quantitative landslide susceptibility assessments in Hulu Kelang area, Malaysia. EJGE 19:545-563

70. Sadr MP, Abbas M, Bashir SS (2014) Landslide susceptibility mapping of Komroud sub-basin using fuzzy logic approach. Geodyn Res Int Bull 2:14-27. doi.org/10.3390/w11071402

71. Sakkas G, Misailidis N, Sakellariou N, Kouskouna G, Kaviris G (2016) Modeling landslide susceptibility in Greece: A weighted linear combination approach using analytic hierarchical process, validated with spatial and statistical analysis. Nat Hazards 84:1873-1904. doi.org/10.1007/s11069016-2523-6

72. Süzen ML, Doyuran V (2004b) A comparison of the GIS based landslide susceptibility assessment methods: Multivariate Versus Bivariate. Environ Geol 45:665-679. doi.org/10.1007/s00254-0030917-8

73. Süzen ML, Kaya B (2011) Evaluation of environmental parameters in logistic regression models for landslide susceptibility mapping. Int J Digit Earth 5:1-18. doi.org/10.1080/17538947.2011.586443

74. Tang C, Zhu J, Qi X, Ding J (2011) Landslides induced by the Wenchuan earthquake and the subsequent strong rainfall event: A case study in the Beichuan area of China. Eng Geol 122:22-33. doi.org/10.1016/j.enggeo.2011.03.013

75. Tangestani MH (2004) Landslide susceptibility mapping using the fuzzy gamma approach in a GIS, Kakan catchment area, southwest Iran. Australian J Earth Sci 51:439-450. doi.org/10.1111/j.14000952.2004.01068.x

76. Tanoli JI, Ningsheng C, Regmi AD, Jun L (2017) Spatial distribution analysis and susceptibility mapping of landslides triggered before and after Mw7.8 Gorkha earthquake along Upper Bhote Koshi, Nepal. Arabian J Geosci 10:13,. doi.org/10.1007/s12517-017-3026-9

77. Taşoğlu I, Keskin Çıtıroğlu K, Mekik H Ç (2016) GIS-based landslide susceptibility assessment: A case study in Kelemen Valley (Yenice-Karabuk, NW Turkey. Environ Earth Sci 75:1295. https://doi.org/10.1007/s12665-016-6098-z

78. Tsangaratos $P$, Benardos $A$ (2014) Estimating landslide susceptibility through an artificial neural network classifier. Nat Hazards 74:3. doi.org/10.1007/s11069-014-1245-x

79. Ullmann T, Büdel C, Baumhauer R, Padashi M (2017) Sentinel-1 sar data revealing fluvial morphodynamics in Damghan (Iran): Amplitude and coherence change detection. Int J Earth Sci Geophy 2:1. doi.org/10.35840/2631-5033/1807

80. Van Westen CJ, Rengers N, Soeters R (2003) Use of geomorphological information in indirect landslide susceptibility assessment. Nat Hazards 30:399-419. doi.org/10.1023/B:NHAZ.0000007097.42735.9e

81. Varnes DJ (1976) Landslides, causes and effects. Bulletin IAEG No 14:205-214 
82. Wang HQ, He J, Liu Y, Sun S (2016) Application of analytic hierarchy process model for landslide susceptibility mapping in the Gangu County, Gansu Province, China, Environ. Earth Sci 75:422. doi.org/10.19111/bulletinofmre.502343

83. Wilson JP, Gallant JC (2000) Digital terrain analysis, Chap. 1, In., Eds., Terrain analysis: Principles and applications, New York, 1-27

84. Yang ZH, Lan HX, Gao X, Li LP, Meng YS, Wu YM (2015) Urgent landslide susceptibility assessment in the 2013 Lushan earthquake-impacted area, Sichuan Province, China. Nat Hazard 75(3):24672487. doi.org/10.1007/s11069-014-1441-8

85. Yiğiter ND (2008) Modelling of disaster information system and management in planning with geographic information systems: Adana case study, Master Thesis (in Turkish), Gazi University, Turkey

86. Yılmaz Ç, Topal T, Süzen ML (2012) GIS-based landslide susceptibility mapping using bivariate statistical analysis in Devrek (Zonguldak-Turkey), Environ. Earth Sci 65(7):2161-2178. doi.org/10.1007/s12665-011-1196-4

87. Yomralıoğlu T (2009) Geographic information systems: basic concepts and applications, 480, ISBN 975-97369-0-X, Istanbul

88. Youssef AM, Al-Kathery M, Pradhan B (2015) Landslide susceptibility mapping at Al-Hasher Area, Jizan (Saudi Arabia) using GIS-based frequency ratio and index of entropy models. Geosci J 19(1):113-134

89. Yüksel N (2007) Usage of statistical techniques and artificial neural networks in producing landslide susceptibility maps based on geographical information systems: Kumluca-Ulus (Bartın) region, Doktorate Thesis (in Turkish), Hacettepe University, Turkey

90. Yüksel N (2007) Usage of statistical techniques and artificial neural networks in producing landslide susceptibility maps based on geographical information systems: Kumluca-Ulus (Bartın) region, Doktorate Thesis (in Turkish), Hacettepe University, Turkey

91. Zhuang J, Peng C, Wang G, Chen X, lqbal J, Guo X (2015) Rainfall thresholds for the occurrence of debris flows in the Jiangjia Gully, Yunnan Province, China. Eng Geol 195, doi.org/10.1016/j.enggeo.2015.06.006

\section{Figures}

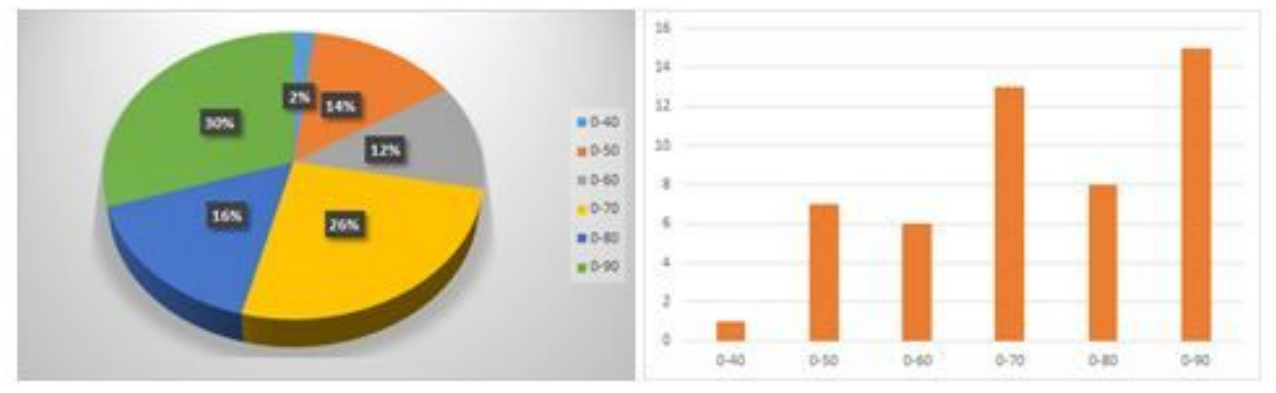


Figure 1

Slope interval graphs for 50 areas at which landslide studies are conducted

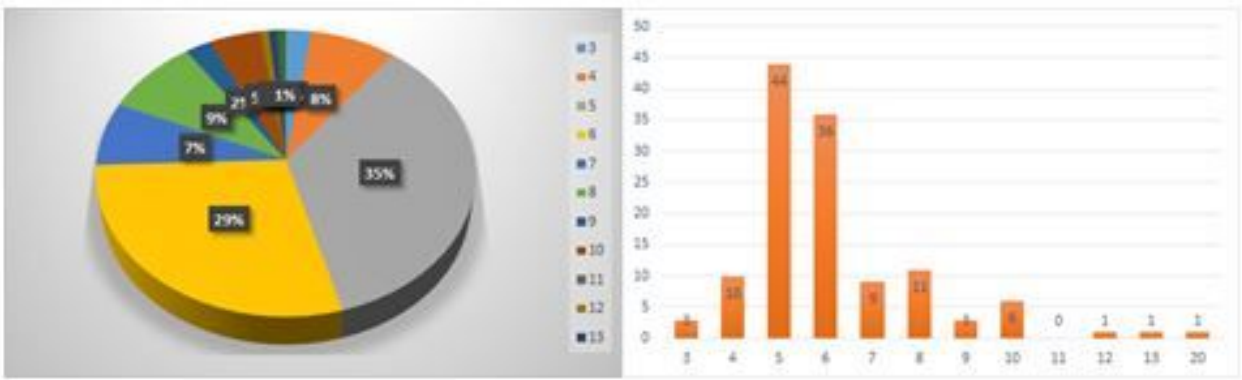

Figure 2

Graphs for the classification groups of the selected landslide studies
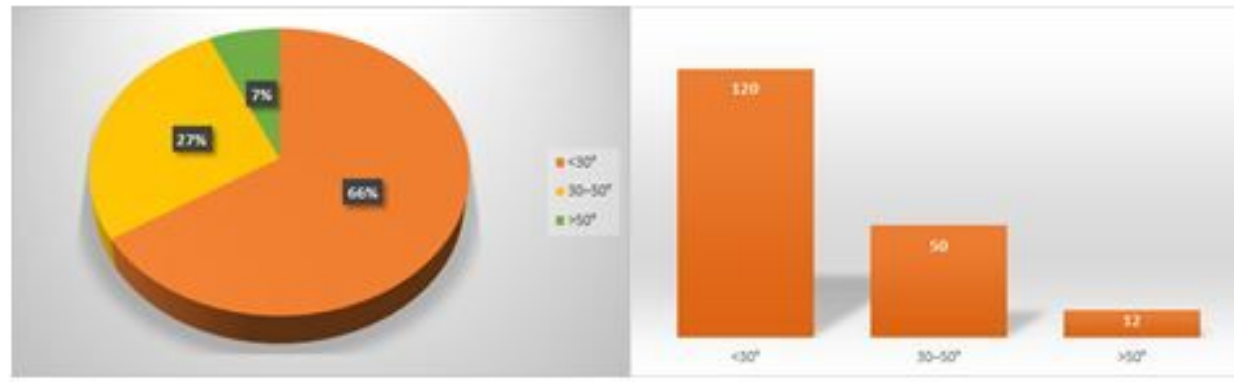

\section{Figure 3}

The realized landslide slope value graphics
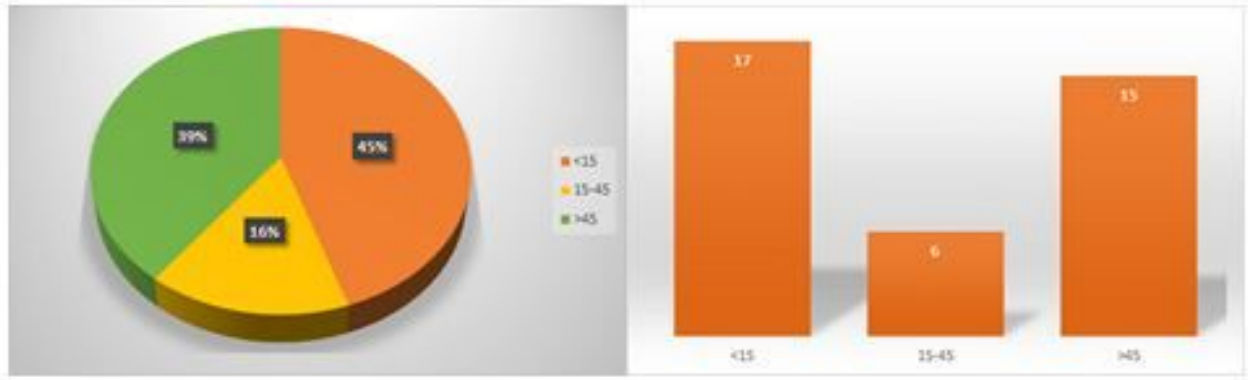

\section{Figure 4}

Slope intervals at which landslides are not or are infrequently encountered 


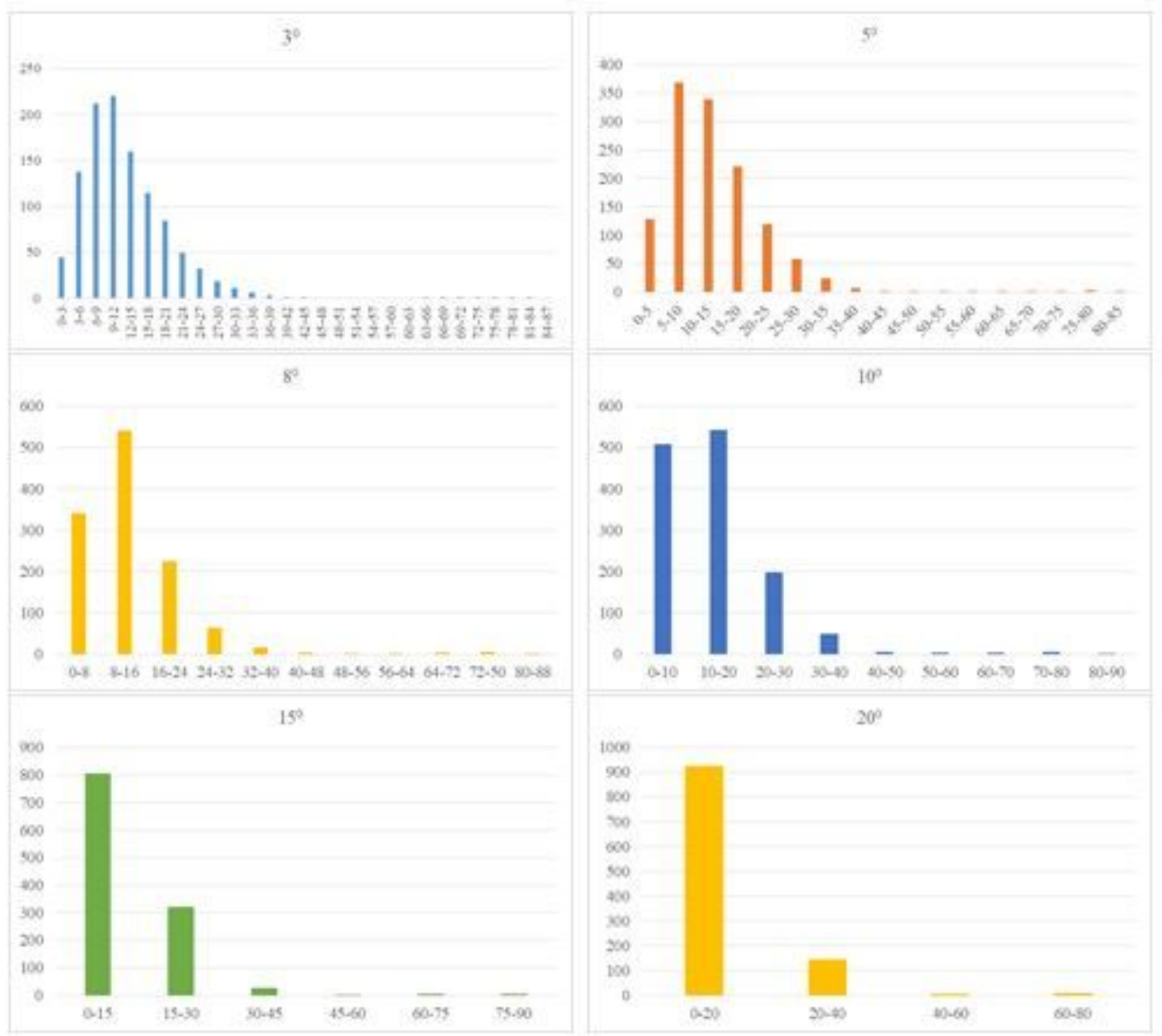

Figure 5

Landslide distributions according to the total areas devoted to slope classes 


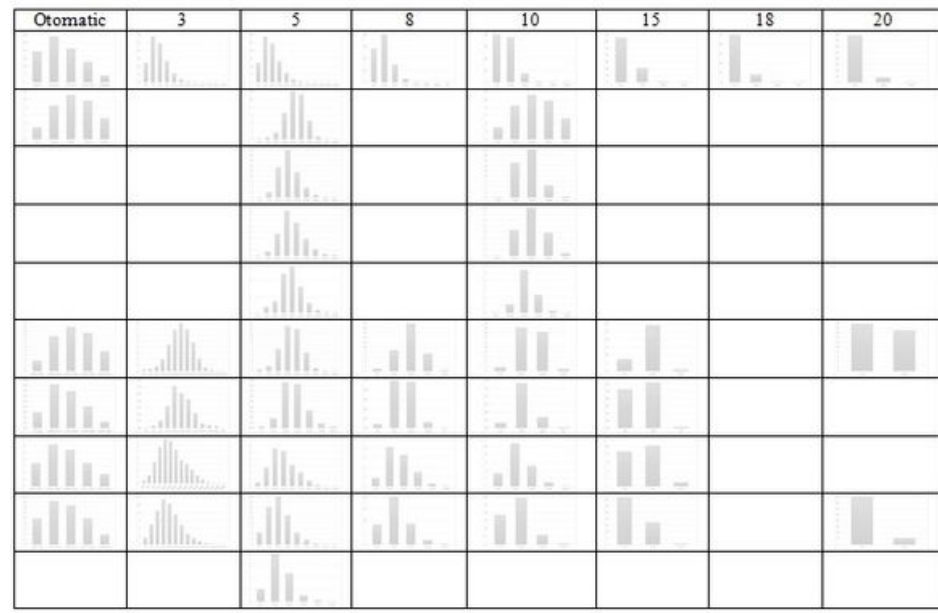

\begin{tabular}{|c|c|c|c|c|c|c|c|}
\hline romatic & 3 & 5 & 8 & 10 & 15 & 18 & 20 \\
\hline & N & . Wh. & $\|$ & II. & I. & 10 & $D_{-}$ \\
\hline & the & . & 11 & 1 & 1. & 1 & . \\
\hline & 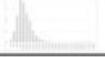 & $\|_{1 .}$ & ill. & 11. & 11. & 1. & $1=$ \\
\hline & illhn & \|\|$_{1}$ & & 11. & $1=$ & & \\
\hline 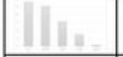 & \& & Hhin & 11 & II. & 11. & I. & $1=$ \\
\hline & 12 & Hi. & & 1. & 1. & 1. & 1. \\
\hline & Ithin. & allis. & 111. & 111. & $1=$ & 1 & 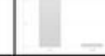 \\
\hline & 14 & Ht... & 11. & 11. & 1. & $=$ & 1 \\
\hline & A & Hit & III. & 1. & 11. & 1. & 1. \\
\hline\|\|$_{1.1}$ & illlin. & Illi. & |11. & 111 & $11=$ & & \\
\hline Oromatic & 3 & & 8 & 10 & 15 & 18 & 20 \\
\hline & 1. & 1. & & & 1. & 1 & 1 \\
\hline & & 1) & & & & & \\
\hline & 1 & $\|_{1+}$ & illi. & All. & 11. & 11. & In \\
\hline & & "lling & & & & & \\
\hline$\|_{11}$ & .illin. & & 11111. & $111=$ & 1 & & \\
\hline\|\|$_{11}$ & D & Hht & illi. & ill. & 11. & II. & 111 \\
\hline 111 & $H$ & $\|_{1 .}$ & hi. & 1. & 11. & 11 & $1=$ \\
\hline .1111. & thillhi. & Illi. & . III. & all & 11 & & \\
\hline 111. & $L_{1}$ & illit. & 11. & 11. & 11. & 111 & 1. \\
\hline 11111. & 14 & \|\|$_{1, t}$ & $A \|_{n .}$ & Al. & 111. & 111 & 11 \\
\hline
\end{tabular}
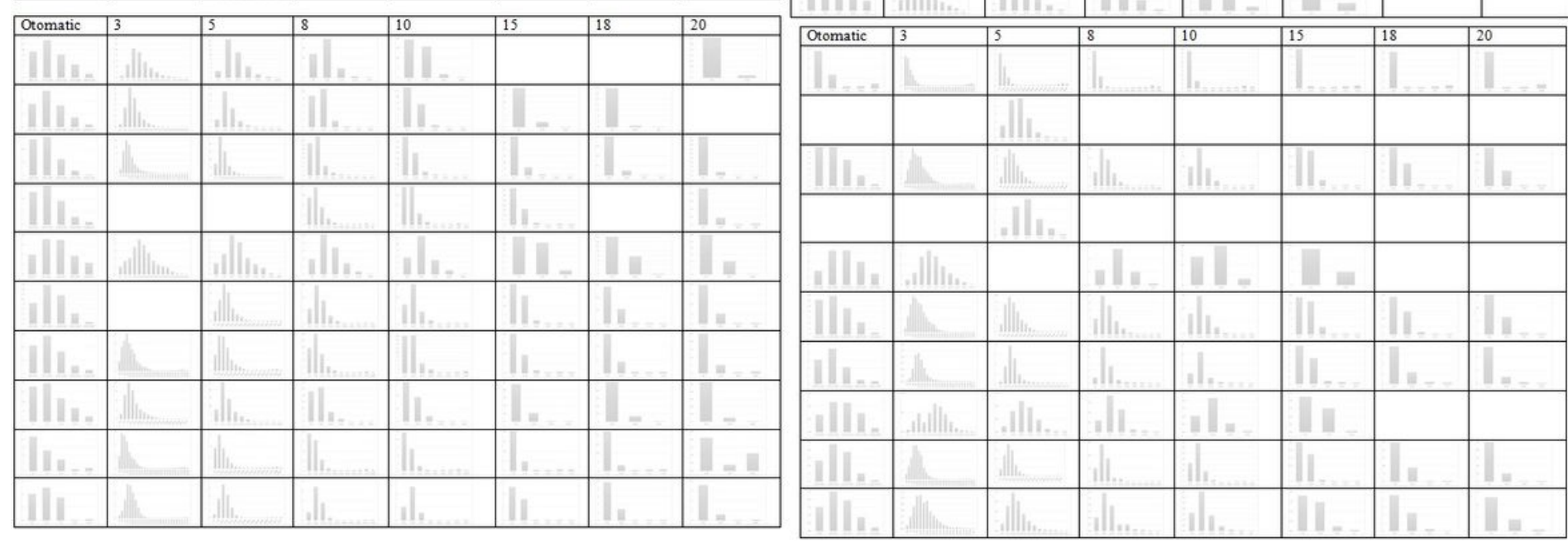

Figure 6

Distribution of landslide areas by slope classes

\section{Supplementary Files}

This is a list of supplementary files associated with this preprint. Click to download.

- Fig7.docx

- supplementgraph.docx

- supplementdata.xlsx

- supplement.docx 